\title{
Productivity and Yield Components of Soybeans under Dose and Potassium Application Period in Piauí Savannah
}

\author{
Fabiano André Petter ${ }^{1}$, Jodean Alves da Silva ${ }^{2}$, Francisco de Alcântara Neto ${ }^{1}$, Leandro Pereira Pacheco ${ }^{1}$, \\ Fernandes Antônio de Almeida ${ }^{1}$, Glenio Guimarães Santos ${ }^{3} \&$ Larissa Borges de Lima ${ }^{4}$ \\ ${ }^{1}$ Department of Agronomy, Plant Science of University Federal of Piauí, Bom Jesus, PI, Brasil \\ ${ }^{2}$ Pos-Graduate Program in Agronomy, Plant Science of University Federal of Piauí, Bom Jesus, PI, Brasil \\ ${ }^{3}$ Department of Agronomy, Soil Science of University Federal of Piauí, Bom Jesus, PI, Brasil \\ ${ }^{4}$ Pos-Graduate of Agronomy, Soil and Water of University Federal of Goiás, Goiânia, GO, Brasil \\ Correspondence: Fabiano André Petter, Pos-Graduate Program in Agronomy, Plant Science of University \\ Federal of Piauí, Bom Jesus, PI 64900-000, Brazil. E-mail: petter@ufpi.edu.br
}

Received: May 7, 2012 Accepted: May 24, 2012 Online Published: July 11, 2012

doi:10.5539/jas.v4n8p173 URL: http://dx.doi.org/10.5539/jas.v4n8p173

\begin{abstract}
The objective of this study was to evaluate the efficiency of rates and application periods of K on soybeans in the Savannah in Piauí. The work was carried out in a dystrophic oxisol. The experimental design was randomized blocks with four replications in a factorial design, the treatments consisted of combinations of five potassium doses $30,60,90,120$ and $150 \mathrm{~kg} \mathrm{ha}^{-1}\left(\mathrm{~K}_{2} \mathrm{O}\right)+$ witness $\left(0 \mathrm{~kg} \mathrm{ha}^{-1}\right)$, applied at four different times: $100 \%$ at soybean sowing, $50 \%$ at sowing and $50 \%$ at 30 days after sowing (DAS), $100 \%$ at $30 \mathrm{DAS}, 50 \%$ at $20 \mathrm{DAS}$ and $50 \%$ to 40 DAS. Evaluated the following variables: height soybean plants, dry biomass, internal efficiency in the use of nutrient-K (IENU-K), number of pods per plant ${ }^{-1}$, number of grains per pod ${ }^{-1}$, a thousand seeds weight, grain harvest index and productivity. There was no effect concerning the period of application of $\mathrm{K}$ in the variables analyzed. Exceptions done for dry biomass and the number of pods per plant ${ }^{-1}$, the other variables were significantly influenced by $\mathrm{K}$ rates. All variables significantly influenced by the application of $\mathrm{K}$ rates showed quadratic response, in which, exception of IENU-K, the curves showed the highest values by applying 83 to $93 \mathrm{~kg}$ $\mathrm{ha}^{-1} \mathrm{~K}_{2} \mathrm{O}$.
\end{abstract}

Keywords: Glycine $\max$ (L.) Merrill, fertilization, agronomic efficiency, crop

\section{Introduction}

Soybean (Glycine max (L.) Merrill) is currently the main economic crop in Brazil, with up to $48 \%$ of the total cultivated area in the country (National Company Supply [CONAB], 2012). The Piauí Savannah is an important area of soybean production in Brazil. Despite favorable environmental conditions to the soybeans cultivation, many research advances for this agricultural region must be obtained (Alcântara Neto, Gravina, Souza \& Bezerra, 2010). The prospect of increase on the fertilizers demand implies the necessity for use of appropriate doses, combined with the time and method of application that allows greater use by the crop.

Potassium is the second element more absorbed by plants and its availability in the soils of the Savannah region are lows (Freitas, Leandro \& Carvalho, 2007), which are highly weathered soils (Silva et al., 2008), being insufficient to supply the appropriate amount by cultures by successive cultivations. The contribution of all these factors makes the management of potassium fertilization (source, rate, method and time of application) is necessary for the maintenance and improvement of crop productivity (Vilela, Souza \& Martha, 2007).

Potassium fertilization on soybeans is usually performed by applying the fertilizer in the planting furrow. However, requires be careful with applications of potassium above $50 \mathrm{~kg} \mathrm{ha}^{-1} \mathrm{~K}_{2} \mathrm{O}$ at planting furrows, to reduce the risks of the salinization effect on seed germination, especially under conditions of water stress. Moreover, the excessive use of potassium in the planting furrow caused losses by leaching, mainly in sandy soils, with low cation exchange capacity (CEC) (Werle, Garcia \& Rosolen, 2008; Bernardi et al., 2009).

The soybean response to potassium fertilization is related to the exploration capacity of $\mathrm{K}$ soil, and to the quantities exported by grains. Furthermore, according to Petter, Pacheco, Alcântara Neto and Santos (2012), the efficiency in 
fertilizer use is closely linked to the edaphic and climatic conditions of each region, thus affecting the dynamics of fertilizer use.

The occurrence of dry spells, common in the Savannah region is an important factors that significantly interfere in the handling of potassium fertilization, mainly because the $\mathrm{K}$ availability to plants depends on its mobility in soil by diffusion, predominantly, a process which, according to Pavinato and Ceretta (2004) is highly dependent on soil moisture.

According to Rheinheimer et al. (2007), the development of techniques for the diagnosis of soil fertility, the recommendation for economic and environmentally appropriate doses of fertilizers for different crops and soil types, is still complex. This fact can be proved by the divergent results (Foloni \& Rosolem, 2008; Guareschi, Gazolla, Souchie \& Rocha, 2008; Bernardi et al., 2009) and the soybean response to K application in the Savannah regions.

Considering the increase in fertilizer prices and the differential response of soybeans to potassium fertilization in Savannah, it is quite important to search for method to optimize fertilization in order to ensure the best performance of the soybean crop. Accordingly, this study aims to evaluate the efficacy of doses and application times of potassium on productivity and the yield components of soybeans in the Piauí Savannah.

\section{Material and Methods}

The experiment was conducted in the Serra do Quilombo during the 2010-2012crop season in Bom Jesus-PI, on soil classified as Oxisol dystrophic typical, sandy clay loam texture, with the following physical and chemical characteristics: $\mathrm{pH}\left(\mathrm{H}_{2} \mathrm{O}\right): 5.0$; P (Mehlich): $36.4 \mathrm{mg} \mathrm{dm}{ }^{-3} ; \mathrm{K}^{+}: 77 \mathrm{mg} \mathrm{dm}{ }^{-3} ; \mathrm{Ca}^{2+}: 2.1 \mathrm{cmol}_{\mathrm{c}} \mathrm{dm}^{-3} ; \mathrm{Mg}^{2+}: 0.4 \mathrm{cmol}_{\mathrm{c}}$ $\mathrm{dm}^{-3} ; \mathrm{Al}^{3+}: 0.2 \mathrm{cmol}_{\mathrm{c}} \mathrm{dm}^{-3} ; \mathrm{H}^{+}+\mathrm{Al}^{3+}: 4.6 \mathrm{cmol}_{\mathrm{c}} \mathrm{dm}^{-3} ; \mathrm{V} \%: 37$; CEC: $\mathrm{cmol}_{\mathrm{c}} 7.3 \mathrm{dm}^{-3} ;$ O.M.: $14.0 \mathrm{~g} \mathrm{~kg}^{-1} ;$ Fe: $129 \mathrm{mg}$ $\mathrm{dm}^{-3}$; Mn: $8.5 \mathrm{mg} \mathrm{dm}$; Zn: $3.7 \mathrm{mg} \mathrm{dm}$; Cu: $1.4 \mathrm{mg} \mathrm{dm}$; Clay: $280 \mathrm{~g} \mathrm{~kg}^{-1}$; Silt: $80 \mathrm{~g} \mathrm{~kg}^{-1}$; sand: $640 \mathrm{~g} \mathrm{~kg}^{-1}$. The experiment was conducted in an area in which soybean monoculture has been done for 8 years and has been receiving annual applications of $500 \mathrm{~kg} \mathrm{ha}^{-1}$ NPK 00-20-20 fertilizer.

The region climate is Aw according global climate classification to Köppen-Geiger, with two well defined seasons. Drought season lasts from May to September and rainy season that goes from October to April. The data on temperature and precipitation that occurred during the experiment are shown in Figure 1.

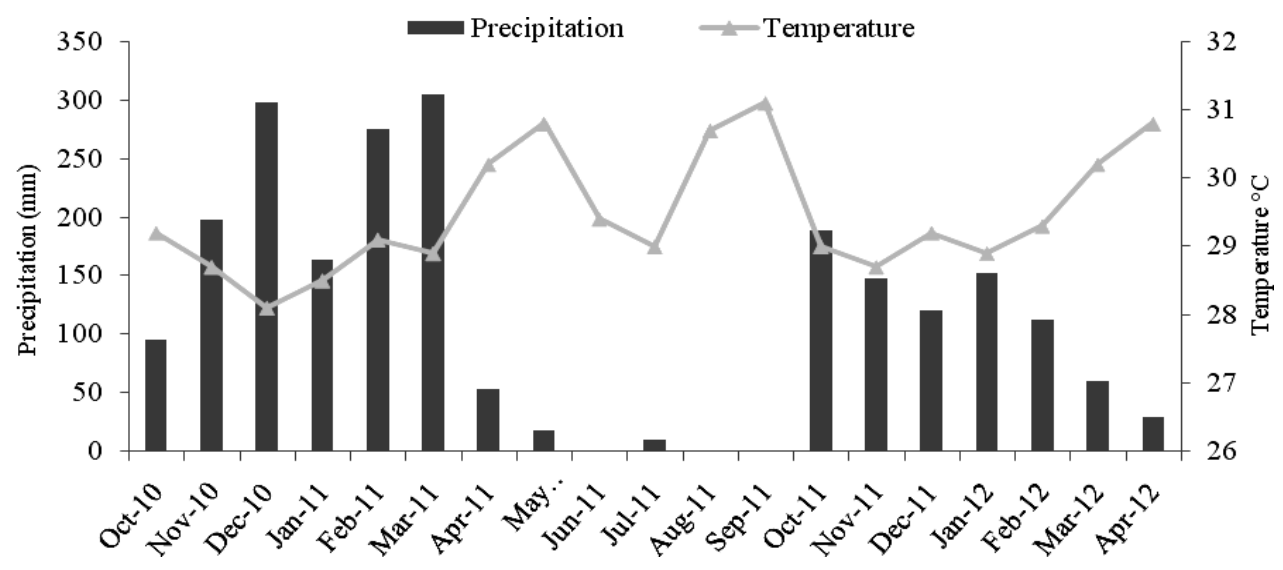

Figure 1. Precipitation $(\mathrm{mm})$ and average temperature $\left({ }^{\circ} \mathrm{C}\right)$ occurred in the study area during the experiment, Bom Jesus, PI

No-till soybean sowing (variety Monsoy 9350) was performed on December 5, 2010 and 2011, by use 13 seeds per meter, spacing $0.5 \mathrm{~m}$ between sowing lines, and a sowing depth of 2-3 cm. The Fertilizer, according the soil analyzes, was done established by applying $400 \mathrm{~kg} \mathrm{ha}^{-1}$ of simple superphosphate.

The experimental design was a randomized block with four replications in a factorial scheme $(5 \times 4)+1$. Treatments consisted of combinations of five potassium doses: 30, 60, 90, 120 and $150 \mathrm{~kg} \mathrm{ha}^{-1}\left(\mathrm{~K}_{2} \mathrm{O}\right)+$ witness (zero kg ha $\left.{ }^{-1}\right)$ applied four times at $100 \%$ at sowing , $50 \%$ at sowing and $50 \%$ at 30 days after sowing (DAS), $100 \%$ at 30 DAS, 50 DAS and $20 \%$ to $50 \%$ at $40 \mathrm{DAS}$, using as source potassium chloride. Each plot consisted of ten sowing lines spaced $0.5 \mathrm{~m}$ and with $5 \mathrm{~m}$ in length, totaling $25.00 \mathrm{~m}^{2}$, being the area useful for the evaluation of $12,00 \mathrm{~m}^{2}$. For the application of manual treatments were carried out distributions broadcast. 
The cultivation treatments (weed control, pests and diseases) were those recommended for the region and for the variety.

On the flowering stage was evaluated the height and dry biomass of plants, in five plants per plot, $\mathrm{K}$ content in leaf tissues, collecting five trifoliate leaves per plot, and chlorophyll content using chlorophyll meter (CFL clorofilLOG 1030), evaluating on three central points of the third trifoliate leaf from the apex to the base stem. By harvest time, we have evaluated the biomass residues and grain yield, with standardization of $14 \%$ moisture. To determine the dry biomass, the plants were carried to forced circulation oven at $65{ }^{\circ} \mathrm{C}$ for 72 hours, and for the determination of $\mathrm{K}$ levels in tissue samples of the dried material, they were subsequently crushed in mill type "Wiley", with a 20 "mesh" sieve, and digested in nitro-perchloric solution and determined by flame photometry.

Using the data of dry matter accumulation and the concentration of potassium in the leaves, we have determined the nutrient use efficiency (NUE), calculated according adaptation of Vitousek (1982), in which the nutrient use efficiency (NUE) is determined by the inverse of the concentration of an element in leaf tissue.

Normally, this efficiency is calculated for the senescent leaves (Vitousek 1982), however, since the assessment was determined at the maximum peak of dry matter accumulation, the soybean plants do not exhibit senescence. Therefore, we have calculated the NUE of living tissue normal activity, which also indicates how many nutrients the plant is using to produce the quantity of biomass. This process as internal efficiency nutrients use (IENU), since it is not taken into account how much of each nutrient plants discard on their senescent leaves, but the amount that is actually being used effectively for conversion in biomass through photosynthesis.

For IENU calculations, the following formula adapted from Vitousek (1982) was used:

$$
\mathrm{IENU}=\left(\mathrm{g} m \cdot(\mathrm{g} n)^{-1}\right)
$$

in which: $\mathrm{g} m$ is the dry biomass of sample in grams and $\mathrm{g} n$ is the amount of nutrients in grams found in the same sample. The higher the IENU is, the higher plant capacity to convert the unit nutrient absorbed in biomass production unit is.

We have also determined the index of grain harvest (IGH) (Fageria \& Santos, 2008), in which:

$$
\mathrm{IGH}=\text { yield grain/yield grain }+ \text { biomass residues }
$$

As for the calculation of relative productivity (RP) (Wendling et al., 2008), we have used the following formula:

$$
\mathrm{RP}=\left(\mathrm{PMSF}^{*} 100\right) / \mathrm{MTE}
$$

in which: RP: relative productivity; PMSF: average productivity of the experiment without fertilizer use; MTE: maximum technique efficiency.

The results (two growing seasons) were subjected to variance analysis, being the averages of the significant parameters in function of $\mathrm{K}$ period application submitted to the Tukey test at $5 \%$ significance level, using the statistical program Sisvar 5.3. For quantitative data (rate), it was performed a regression analysis in which the equations were adjusted using the correlation parameters and variable determinations, in function the application rates of potassium fertilizer, using the statistical program SigmaPlot. For the significance effect of the variables (coefficients) of the equations, we have used the " $t$ " Student test at 5\% probability.

The maximum technique efficient (MTE) was determined, in which, from the first derivative of each regression equation and equating them to zero, there was obtained the point of maximum dose of $\mathrm{K}$. The values were substituted in their main equations and the values of MET were obtained.

\section{Results and Discussion}

There was no significant effect of potassium application period in the variables analyzed (Table 1). These results differ from those experienced by Lana, Hamawaki, Lima and Zanão Júnior (2002) for dry biomass, however, corroborate those obtained by Aratani, Lazarini and Marques (2007), Moterle et al. (2009) and Gonçalves Junior, Nacke, Marengoni, Carvalho, and Coelho (2010) for height, number of pods plant ${ }^{-1}$, number of seeds pod $^{-1}$ and a thousand seeds weight. As for productivity, results are inconsistent, since, in some studies (Foloni \& Rosolem, 2008; Guareschi et al., 2008) there was response to the productivity in function of application periods, while in other studies, no answer has been verified (Aratani et al., 2007; Bernardi et al., 2009). 
Table 1. Yeld components of soybean under potassium application period in Bom Jesus, PI

\begin{tabular}{|c|c|c|c|c|}
\hline Application time & $\begin{array}{l}\text { Height of plants } \\
(\mathrm{cm})\end{array}$ & $\begin{array}{l}\text { Dry biomass } \\
\left(\mathrm{g} 5 \text { plants }^{-1}\right)\end{array}$ & $\begin{array}{c}\text { IENU-K } \\
\left(\mathrm{g} \mathrm{g}^{-1}\right)\end{array}$ & $\begin{array}{c}\text { Number of pods } \\
\text { plant }^{-1}\end{array}$ \\
\hline $100 \%$ at sowing & $62,6^{\text {ns }}$ & $95,0^{\text {ns }}$ & $88^{\text {ns }}$ & $78^{\mathrm{ns}}$ \\
\hline $\begin{array}{l}50 \% \text { sowing }+50 \% 30 \\
\text { DAS }\end{array}$ & 63,2 & 91,4 & 90 & 76 \\
\hline $100 \%$ at $30 \mathrm{DAS}$ & 62,7 & 94,7 & 85 & 76 \\
\hline $\begin{array}{l}50 \% 20 \text { DAS }+50 \% 40 \\
\text { DAS }\end{array}$ & 63,4 & 94,2 & 83 & 70 \\
\hline Application time & $\begin{array}{l}\text { Number of grains } \\
\text { pod }^{-1}\end{array}$ & $\begin{array}{l}\text { Thousand seed } \\
\text { weight }(\mathrm{g})\end{array}$ & IGH & $\begin{array}{l}\text { Grain productivity } \\
\left(\mathrm{kg} \mathrm{ha}^{-1}\right)\end{array}$ \\
\hline $100 \%$ at sowing & $2,1^{\mathrm{ns}}$ & $146^{\mathrm{ns}}$ & $0,72^{\mathrm{ns}}$ & $3.714^{\mathrm{ns}}$ \\
\hline $\begin{array}{l}50 \% \text { sowing }+50 \% 30 \\
\text { DAS }\end{array}$ & 2,0 & 151 & 0,75 & 3.815 \\
\hline $100 \%$ at $30 \mathrm{DAS}$ & 2,0 & 149 & 0,80 & 3.867 \\
\hline $\begin{array}{l}50 \% 20 \text { DAS }+50 \% 40 \\
\text { DAS }\end{array}$ & 2,0 & 145 & 0,74 & 3.707 \\
\hline
\end{tabular}

ns - not significant; DAS - days after sowing; IENU - internal efficiency nutrients use - potassium; IGH - index of grain harvest.

The lack of significant effect of $\mathrm{K}$ application period of the mentioned parameters may be due to the use, by

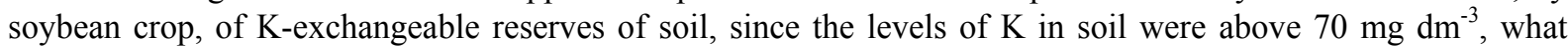
according Vilela et al. (2004) is within the range considered optimal as for the Savannah region. For these soil conditions in the Piauí Savannah, the choice of making the application of K in installments or all at planting should be based on the costs and/or optimization of application operations. However, another aspect to be considered, should be the possibility of periods of low available water on the sowing, which may lead to reduced germination when high doses of $\mathrm{K}_{2} \mathrm{O}$ are used.

Although the $\mathrm{K}$ doses have significantly influenced plant height, the same was not observed for dry biomass (Figure 2). For both parameters, there was a similar pattern, where the regression equations were the curves the adjusted to a quadratic model, however, only the equation parameters the plant height were significant . The data revealed a greater height at $90 \mathrm{~kg} \mathrm{ha}^{-1} \mathrm{~K}_{2} \mathrm{O}$. These results are consistent with those seen by Lana et al. (2002), in which the application of $90 \mathrm{~kg} \mathrm{ha}^{-1} \mathrm{~K}_{2} \mathrm{O}$ has provided the greatest height of soybean plants.

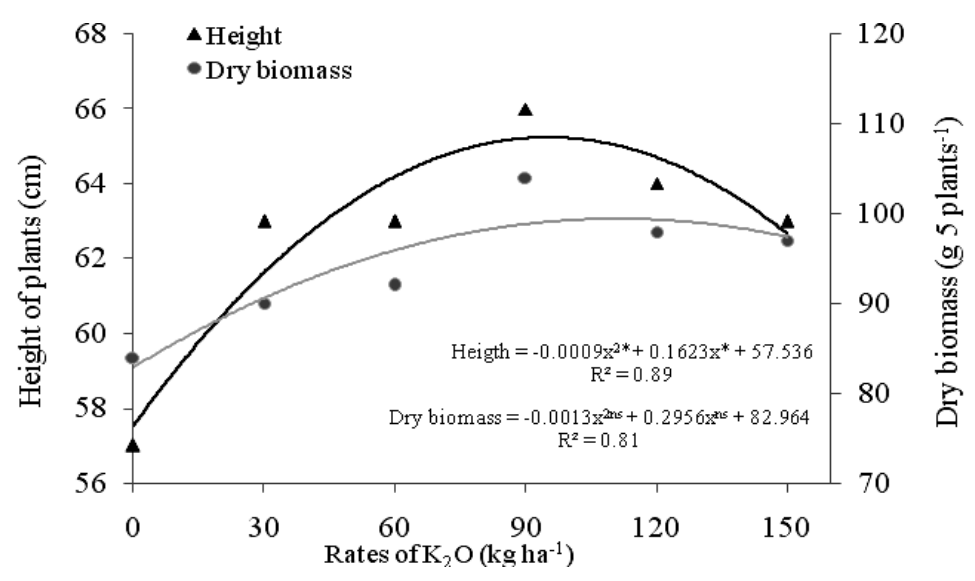

Figure 2. Height and dry biomass of soybean plants as a function of doses of potassium in Bom Jesus, PI. ${ }^{\text {ns }}$ not significant, *significant at 5\% probability by Student "t" of Student

The application of increasing doses of $\mathrm{K}_{2} \mathrm{O}$ provided linear increase in $\mathrm{K}$ concentration in soybean leaves (Figure 3A). An increase in K content in soybean was also verified by Serafim et al. (2012) with the application of increasing doses of potassium chloride. Already the internal efficiency in the use of nutrient-potassium (IENU-K) showed a quadratic behavior (Figure 3B). The value of IENU shows how much dry biomass plants 
can produce with a certain quantity of nutrients in plant tissue. It can be seen that increasing the concentration of $\mathrm{K}$ in leaves does not result in a proportional increase in biomass production, indicating that the higher the $\mathrm{K}$ in leaf the lower the conversion efficiency of biomass is. It can be clearly seen in Figure 3, that the IENU is inversely proportional to the concentration of $\mathrm{K}$ in leaf tissue. In general, the higher values of IENU were observed for doses up to $90 \mathrm{~kg} \mathrm{ha}^{-1} \mathrm{~K}_{2} \mathrm{O}$, while the lowest values were observed for doses of $120 \mathrm{~kg} \mathrm{ha}^{-1}$ and 150 $\mathrm{kg} \mathrm{ha}^{-1} \mathrm{~K}_{2} \mathrm{O}$ and in larger $\mathrm{K}$ concentrations in leaf tissue.
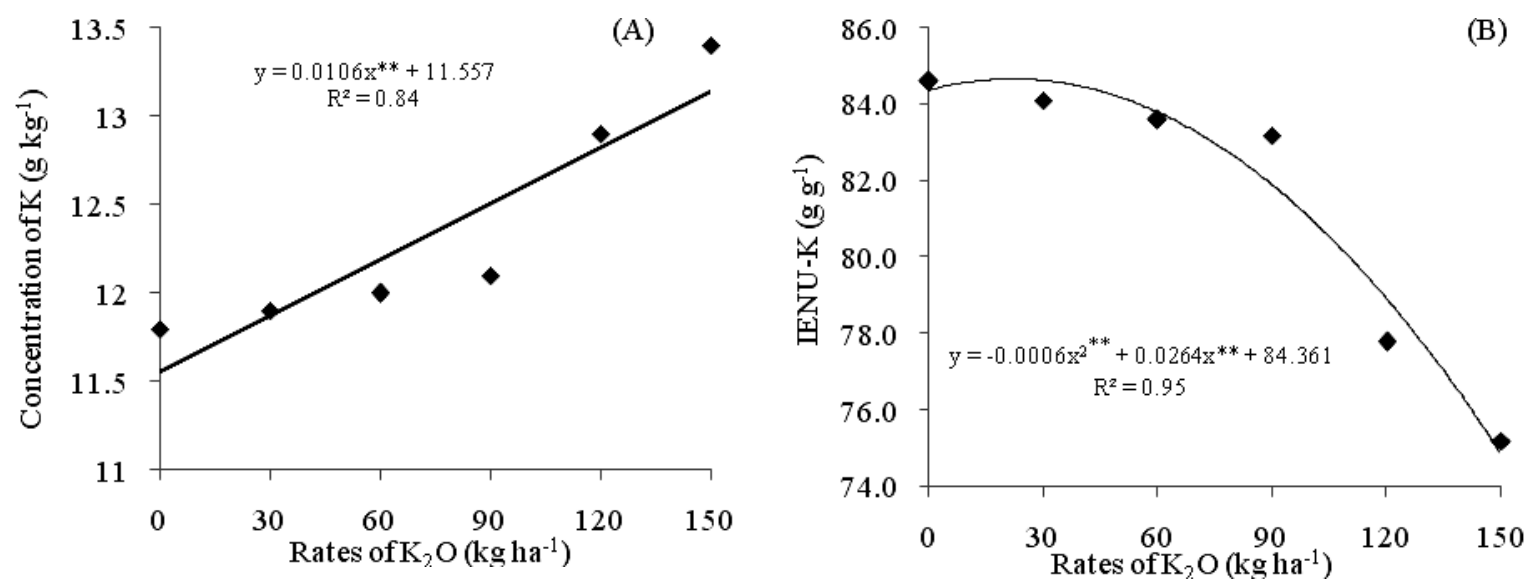

Figure 3. Concentration of K (A) and internal efficiency nutrients use - potassium (B) in leaves of soybean as a function of doses of potassium in Bom Jesus, PI, Brazil. ** significant at 1\% probability by Student " $t$ " of

Student

The linear increase in $\mathrm{K}$ concentration in the leaf tissue with an increase in $\mathrm{K}_{2} \mathrm{O}$ applied dose (Figure $3 \mathrm{~A}$ ), shows that there is a "luxury consume" by this crop, since the maximum productivity (3961 $\mathrm{kg} \mathrm{h}^{-1}$ ) estimated (Figure 6A) was obtained with a $97 \mathrm{~kg} \mathrm{ha}^{-1} \mathrm{~K}_{2} \mathrm{O}$ dose and with an estimated $\mathrm{K}$ concentration of $12.5 \mathrm{~g} \mathrm{~kg}^{-1}$ in leaves. This " luxury consume " can also be seen by the maximum IENU-K, which was verified with a $22 \mathrm{~kg} \mathrm{ha}^{-1} \mathrm{~K}_{2} \mathrm{O}$ dose, which would provide an estimated yield of $3570 \mathrm{~kg} \mathrm{ha}^{-1}$ and $11.8 \mathrm{~g} \mathrm{~kg}^{-1} \mathrm{~K}$ content in leaves thus, resulting, in a relative productivity (RP) of $90 \%$. These results are similar to those obtained by Wendling et al. (2008), who have found RP of soybean of $98 \%$ at a dose of $22 \mathrm{~kg} \mathrm{ha}^{-1} \mathrm{~K}_{2} \mathrm{O}$ in Oxisol with $\mathrm{K}$ content rated as high. The IENU proposed in this study proves to be a good alternative to help in the recommendation of $\mathrm{K}$ fertilization in Savannah soils in Piauí.

Considering a critical RP of $90 \%$ as for soybean (Schlindwein, 2003), it appears that doses under the MTE are sufficient to provide a satisfactory productivity. However, considering the amount of $\mathrm{K}$ exported by this crop, which according to Bataglia and Mascarenhas (1988) is approximately $20 \mathrm{~kg} \mathrm{ton}^{-1}$ of grain, it is recommended to do a minimum of maintenance fertilization $\left(60 \mathrm{~kg} \mathrm{ha}^{-1} \mathrm{~K}_{2} \mathrm{O}\right)$. On the other hand, in soils with a $\mathrm{K}$ rate classified as high and during years of low expectation as for soybean prices in the market, producers may choose to fertilization around $30 \mathrm{~kg} \mathrm{ha}^{-1}$ to keep an approximate $90 \% \mathrm{RP}$, since this amount can be applied in advance, at the time of sowing or at covering, as observed in this study and Foloni and Rosolem (2008). However, it is important to always check the $\mathrm{K}$ levels in soil during the following year, in order not to allow the levels to falling below a critical rate, since, Scherer (1998) affirms that annual applications of $40 \mathrm{~kg} \mathrm{ha}^{-1} \mathrm{~K}_{2} \mathrm{O}$ are insufficient to maintain constant $\mathrm{K}$ levels in soil, causing a decrease in availability over the years.

The number of pods plant ${ }^{-1}$ was significantly influenced by the applied $\mathrm{K}_{2} \mathrm{O}$ levels (Figure 4A). The equation was adjusted in a square way, high lightening the highest number of pods plant ${ }^{-1}$ at doses between of $60 \mathrm{~kg} \mathrm{ha}^{-1}$ and $90 \mathrm{~kg} \mathrm{ha}^{-1} \mathrm{~K}_{2} \mathrm{O}$. These data corroborate those obtained by Gonçalves et al. (2010), who found an increase iof the number of pods plant ${ }^{-1}$ with the application of $60 \mathrm{~kg} \mathrm{ha}^{-1} \mathrm{~K}_{2} \mathrm{O}$, however, this results differ from Aratani et al. (2007), who noticed no effect of increasing $\mathrm{K}$ doses. This difference in results can be attributed to the edaphic and climatic conditions of each region, since in both studies, $\mathrm{K}$ levels were considered as average, with $68 \mathrm{mg}$ $\mathrm{dm}^{-3}$ and $70 \mathrm{mg} \mathrm{dm}^{-3}$, respectively. 

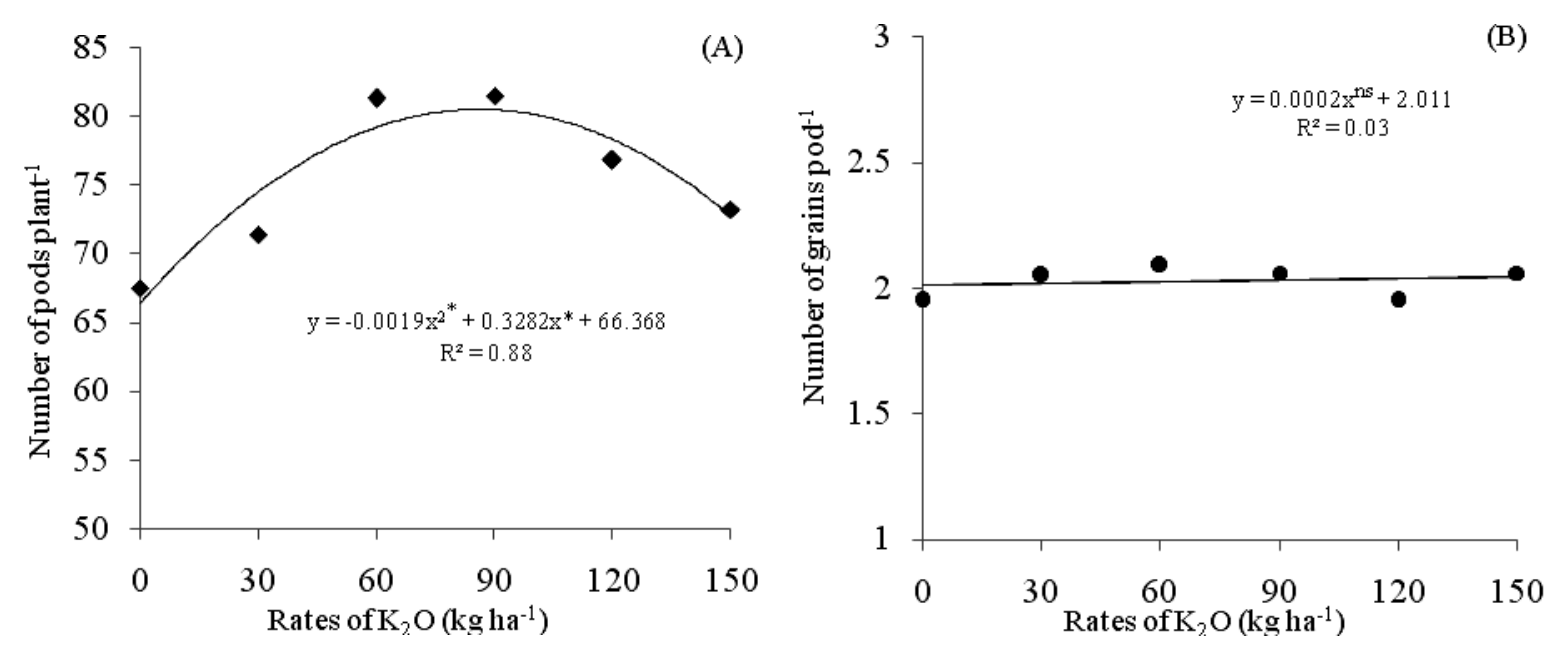

Figure 4. Number of pods plant ${ }^{-1}$ (A) e number of grains $\operatorname{pod}^{-1}(B)$ in soybean plants as a function of doses of potassium in Bom Jesus, PI. ${ }^{\text {ns }}$ not significant, *significant at $5 \%$ probability by Student "t" of Student

Probably, the positive effect of the intermediate $\mathrm{K}$ doses is related to the high metabolic activity in meristematic regions, such as in the axillary buds, since there is $\mathrm{K}$ preferable accumulation in young tissue and in intensive metabolism (Larcher, 2000). However, high doses of $\mathrm{K}_{2} \mathrm{O}$ can cause greater accumulation of $\mathrm{K}$ in tissues (Figure $3 \mathrm{~A}$ ) and by the antagonistic effect, providing induced deficiency of $\mathrm{Ca}$ and $\mathrm{Mg}$, as observed by Carvalho and Barbosa (2003) in cotton crops. The authors observed that with increasing K concentration in leaf, there was a reduction in $\mathrm{Ca}$ and $\mathrm{Mg}$. Due to a direct involvement of $\mathrm{Ca}$ in the formation of the pollen tube germination and pollen grain (Bevilaqua, Silva Filho, \& Possenti, 2002), its deficiency can reduce the formation and pod filling. These authors observed yet that application of Ca has provided a greater increase in the number of pods plant ${ }^{-1}$ in soybean.

As for the number of grains $\operatorname{pod}^{-1}$, there was no significant effect of potassium application (Figure 4B), confirming the results of Gonçalves et al. (2010). The number of grains per pod is influenced by a genetic characteristic of this cultivar and by the nutritional status of the plant, thus explaining the lack of effect of $\mathrm{K}$ doses in this study, since the levels of $\mathrm{K}$ in soil were found within the range considered as high for the Savannah region. The effect of the absence of $\mathrm{K}$ application could, probably, manifest at low availability in the soil, being able in a $\mathrm{K}$ deficiency situation, to cause an increase in the number of empty lobes, as verified (Serafim et al., 2012).

Significant effects of $\mathrm{K}$ application were observed as for the variable a thousand seeds weight (Figure 5). All doses provided a greater seed weight if compared to control, especially the $90 \mathrm{~kg} \mathrm{ha}^{-1} \mathrm{~K}_{2} \mathrm{O}$ dose. These data differ from those experienced by Gonçalves et al. (2010), however, corroborate those obtained by Serafim et al. (2012). It is possible to observe that the equation describing the behavior of the variable thousand seeds weight to $\mathrm{K}$ application follows the same trend of the equations that describe the accumulation of biomass and index of grain harvest (IGH), since the last one expresses the crop efficiency of converting biomass into grain productivity. The points of maximum dry biomass of the variables and equations IGH were $84 \mathrm{~kg} \mathrm{ha}^{-1}$ and 113 $\mathrm{kg} \mathrm{ha}^{-1} \mathrm{~K}_{2} \mathrm{O}$ respectively, while the largest thousand seed weight was provided by the $94 \mathrm{~kg} \mathrm{ha}^{-1} \mathrm{~K}_{2} \mathrm{O}$ dose. These data show that there was a pattern of translocation of assimilates to the seeds, similar to the accumulation of biomass. 


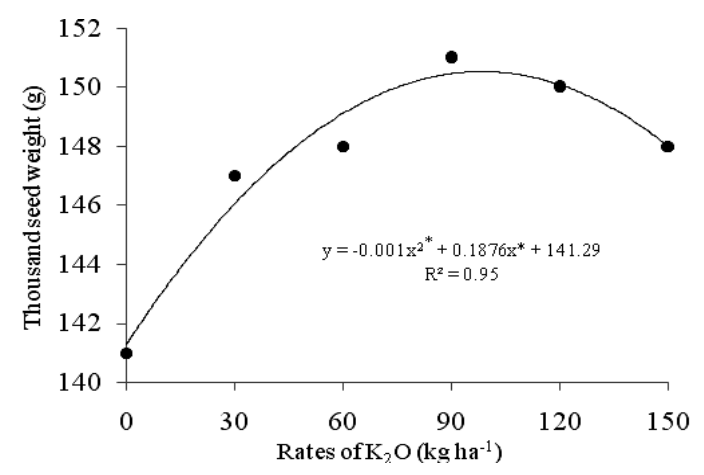

Figure 5. Thousand seed weight in soybean plants as a function of doses of potassium in Bom Jesus, PI.

*significant at $5 \%$ probability by Student " $t$ " of Student

No matter the time of $\mathrm{K}$ application, the yield was significantly influenced by the doses applied (Figure 6A). The equation fit significantly in a quadratic way, showing maximum productivity with the application of $90 \mathrm{~kg} \mathrm{ha}^{-1}$ $\mathrm{K}_{2} \mathrm{O}$. The maximum productivity or maximum technical efficiency (MTE) was $3961 \mathrm{~kg} \mathrm{ha}^{-1}$ obtained with the estimated dose of $97 \mathrm{~kg} \mathrm{ha}^{-1} \mathrm{~K}_{2} \mathrm{O}$. Lana et al. (2002) and Foloni and Rosolem (2008) also found an increase in soybean yield by applying $90 \mathrm{~kg} \mathrm{ha}^{-1} \mathrm{~K}_{2} \mathrm{O}$ in Savannah soils with low and medium concentration of $\mathrm{K}$, respectively. Additionally, Gonçalves et al. (2010) found an increase in soybean yield with application of a $120 \mathrm{~kg}$ $\mathrm{ha}^{-1} \mathrm{~K}_{2} \mathrm{O}$ dose in soils with medium K content. However, Aratani et al. (2007) and Bernardi et al. (2009), have noticed no effect of $\mathrm{K}_{2} \mathrm{O}$ in soils with medium to high $\mathrm{K}$ concentration.

The controversial results seem to be clearly presented concerning the period of application and $\mathrm{K}$ concentrations to be used in soils in the Savannah region. These results reinforce the necessity to define the function of potassium fertilization on soil related to the specific climatic conditions of each region, not considering the possibility of extrapolating fertilizer recommendations from other regions, even within the same biome.

(A)

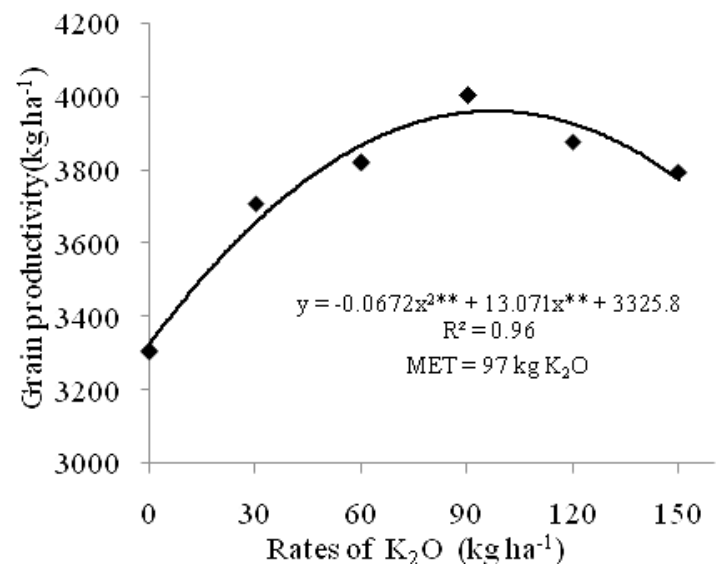

(B)

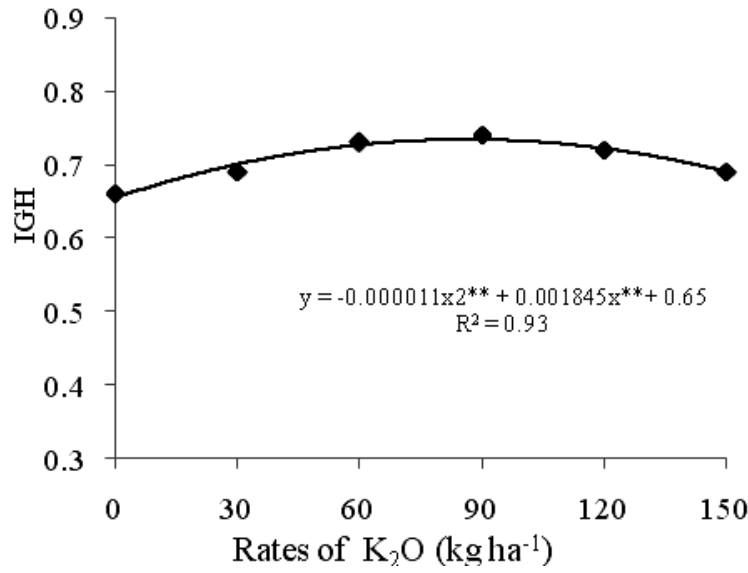

Figure 6. Grain productivity (A) and index of grain harvest (B) in soybean plants as a function of doses of potassium in Bom Jesus, PI. MET: maximum technique efficient. **and *significant at $1 \%$ and $5 \%$ probability by Student "t" of Student

The decrease in grain productivity observed with applications of $120 \mathrm{~kg} \mathrm{ha}^{-1}$ and $150 \mathrm{~kg} \mathrm{ha}^{-1} \mathrm{~K}_{2} \mathrm{O}$ may be due to nutritional imbalance of $\mathrm{K}$ with $\mathrm{Ca}$ and $\mathrm{Mg}$. The absorption of large $\mathrm{K}$ amounts can reduce the absorption or the physiological availability of $\mathrm{Ca}$ and $\mathrm{Mg}$ (Marschner, 1995). Another explanation may be attributed to leaching due to the low CEC and OM in the soil under study.

Therefore, the availability of $\mathrm{K}$ in soils, should not be analyzed in isolation, seeking the offertilizers recommendation, taking in account $\mathrm{Ca}$ and $\mathrm{Mg}$ values. Considering the equation adapted from Castro and Meneghelli (1989), in which the class of soil response to potassium fertilizer is a function of the balance between 
the bases, i.e., the response $\mathrm{K}=\mathrm{K} / \sqrt{ }(\mathrm{Ca}+\mathrm{Mg})\left(\mathrm{cmol}_{\mathrm{c}} \mathrm{dm}^{-3}\right)$, the soil of this study is highly responsive. Accordingly, it can be explained, partly, the response of soybean to $\mathrm{K}$ application in the present study, even with medium $\mathrm{K}$ index in the soil $\left(77 \mathrm{mg} \mathrm{dm}^{-3}\right)$ according to the classification of Savannah soils for yearly crops.

As the dry biomass, a thousand seed weight and productivity, the IGH has followed the same behavior of response as for these variables, being quadratic equation adjusted in which the largest IGH was provided with $90 \mathrm{~kg} \mathrm{ha}^{-1}$ $\mathrm{K}_{2} \mathrm{O}$ (Figure 6B). Quadratic behavior in the IGH was also observed by Sant'Ana, Santos and Silerira (2011) as for bean crop with $\mathrm{N}$ applications. According to Fageria and Santos (2008), there is positive correlation between IGH and grain productivity. The maximum value of IGH estimated by the equation was 0.74 with the estimated dose of $84 \mathrm{~kg} \mathrm{ha}^{-1} \mathrm{~K}_{2} \mathrm{O}$. These results demonstrate that there was a good conversion of dry matter in grains.

\section{Conclusions}

There is no effect of the period in which the $\mathrm{K}_{2} \mathrm{O}$ was applied in Savannah soils. The yield components, number of pods plant ${ }^{-1}$ and a thousand seeds weight are influenced by $\mathrm{K}_{2} \mathrm{O}$ levels, with emphasis on the dose of $90 \mathrm{~kg} \mathrm{ha}^{-1}$, which provided the highest values for these variables. The grain productivity and index grain harvest showed higher values with applications from 83 to $93 \mathrm{~kg} \mathrm{ha}^{-1} \mathrm{~K}_{2} \mathrm{O}$. The application of $30 \mathrm{~kg} \mathrm{ha}^{-1} \mathrm{~K}_{2} \mathrm{O}$ in Piauí Savannah soils with $\mathrm{K}$ levels above $70 \mathrm{mg} \mathrm{dm}^{-3}$ are sufficient to maintain the relative yield above $90 \%$, however it is recommended to apply a maintenance fertilization at least;

\section{References}

Alcântara Neto, F., Gravina, G. A., Souza, N. O. S., \& Bezerra, A. A. C. (2010). Adubação fosfatada na cultura da soja na microrregião do Alto Médio Gurguéia. Revista Ciência Agronômica, 4, 266-271.

Aratani, R. G., Lazarini, E., \& Marques, R. R. (2007). Adubação potássica na cultura da soja em duas épocas de semeadura. Revista Brasileira de Ciências Agrárias, 2, 208-211.

Bernardi, A. C. C., Oliveira Júnior, J. P., Leandro, W. M., Mesquita, T. G. S., Freitas, P. L., \& Carvalho, M. C. S. (2009). Doses e formas de aplicação da adubação potássica na rotação soja, milheto e algodão em sistema plantio direto. Pesquisa Agropecuária Tropical, 39, 158-167.

Bevilaqua, G. A. P., Silva Filho, P. M., \& Possenti, J. C. (2002). Aplicação foliar de cálcio e boro e componentes de rendimento e qualidade de sementes de soja. Ciencia Rural, 32, 31-34.

Carvalho, M. C. S., \& Barbosa, K. A. (2003). Resposta do algodoeiro a doses e épocas de adubação potássica em solo de baixa fertilidade no cerrado de Goiás. Comunicado técnico 200.

Castro, A. F., \& Meneghelli, N. A. (1989). As relações $\mathrm{K}+/(\mathrm{Ca} 2++\mathrm{Mg} 2+)^{1 / 2}$ e $+/(\mathrm{Ca} 2++\mathrm{Mg} 2+)$ no solo e as respostas a adubação potássica. Pesquisa Agropecuária Brasileira, 24, 751-760.

Companhia Nacional E Abastecimento (CONAB). (2012). Acompanhamento da safra 2012. Brasil. http://www.conab.gov.br/safras.asp

Fageria, N. K., \& Santos, A. B. dos. (2008). Yield physiology of dry bean. Journal of Plant Nutrition, 31, 983-1004. http://dx.doi.org/10.1080/01904160802096815

Foloni, J. S. S., \& Rosolem, C. A. (2008). Produtividade e acúmulo de potássio na soja em função da antecipação da adubação potássica no sistema plantio direto. Revista Brasileira de Ciência do Solo, 32, 1549-1561.

Freitas, R. J., Leandro, W. M., \& Carvalho, M. C. S. (2007). Efeito da adubação potássica via solo e foliar sobre a produção e a qualidade da fibra em algodoeiro (Gossypium hirsutum L.). Pesquisa Agropecuária Tropical, $37,106-112$.

Gonçalves Júnior, A. C., Nacke, H., Marengoni, N. G., Carvalho, E. A., \& Coelho, G. F. (2010). Produtividade e componentes de produção da soja adubada Com diferentes doses de fósforo, potássio e zinco. Ciência e Agrotecnologia, 34, 660-666.

Guareschi, R. S., Gazolla, P. R., Souchie, E. L., \& Rocha, A. C. (2008). Adubação fosfatada e potássica na semeadura e a lanço antecipada na cultura da soja cultivada em solo de Cerrado. Semina: Ciências Agrárias, 29, 769-774.

Lana, R. M. Q., Hamawaki, O. T., Lima L, M. L., \& Zanão Júnior, L. A. (2002). Resposta da soja a doses e modos de aplicação de potássio em solo de cerrado. Bioscience Journal, 8, 17-23.

Larcher, W. (2000). Ecofisiologia Vegetal. Rima Artes e Textos, São Carlos, p. 531.

Marschner, H. (1995). Mineral Nutrition of Higher Plants. London: Academic Press, p. 889. 
Mascarenhas, H. A. A., Bulisani, E. A., Miranda, M. A. C., Pereira, J. C. V. N. A., \& Braga, N. R. (1988). Deficiência de potássio em soja no Estado de São Paulo: melhor entendimento do problema e possíveis soluções. O Agronômico, 40, 34-43.

Pavinato, P. S., \& Ceretta, C. A. (2004). Fósforo e potássio na sucessão trigo/milho: épocas e formas de aplicação. Ciência Rural, 34, 1779-1784.

Petter, F. A., Pacheco, L. P., Alcântara Neto, F., \& Santos, G. G. (2012). Respostas de cultivares de soja à adubação nitrogenada tardia em solos de cerrado. Revista Caatinga, 25, 67-72.

Rheinheimer, D. S., Silva, L. S., Ceretta, C. A., Kaminski, J., \& Pellegrini, J. B. R. (2007). Desafios da fertilidade do solo: modelo e interdisciplinaridade. Revista Brasileira de Ciência do Solo, 32, 28-36.

Sant'Ana, E. V. P., Santos, A. B., \& Silveira, P. M. (2011). Eficiência de uso de nitrogênio em cobertura pelo feijoeiro irrigado. Revista Brasileira de Engenharia Agrícola e Ambiental, 15, 458-462.

Scherer, E. E. (1998). Resposta da soja à adubação potássica em Latossolo Húmico distrófico num período de doze anos. Revista Brasileira de Ciência do Solo, 22, 49-55.

Schlindwein, J. A. (2003). Calibração de métodos de determinação e estimativa de doses de fósforo e potássio em solos sob sistema plantio direto. Porto Alegre, Universidade Federal do Rio Grande do Sul, 169 p. (Tese de Doutorado).

Serafim, M. E., Ono, F. B., Zeviani, W. M., Novelino, J. O., \& Silva, J. V. (2012). Umidade do solo e doses de potássio na cultura da soja. Revista Ciência Agronômica, 43, 222-227.

Silva, V. A., Marchi, G., Guilherme, L. R. G., Lima, J. M., Nogueira, F., \& Guimarães, P. T. G. (2008). Kinetics of $\mathrm{K}$ release from soils of Brazilian coffee regions: effect of organic acids. Revista Brasileira de Ciência do Solo, 32, 533-540.

Vilela, L., Souza, D. M. G., \& Martha Jr., G. B. (2007). Adubação potássica e com micronutrientes. In: Cerrados: uso eficiente de corretivos e fertilizantes em pastagens. (eds. Martha Jr., G. B., Vilela, L., \& Souza, D. M. G.) Planaltina, DF: Embrapa Cerrados, 179-188.

Vilela, L., Souza, D. M. G., \& Silva, J. E. (2004). Adubação potássica. In: Cerrado: Correção do solo e adubação. (eds. Souza, D.M.G.; Lobato, E.) 2ª ed. Brasília, DF: Embrapa Informação Tecnológica, 169-183.

Vitousek, P. M. (1982). Nutrient cycling and nutrient use efficiency. American Naturalist, 119, 553-572.

Wendling, A., Eltz, F. L. F., Cubilaa, M. M., Amado, T. J. C., \& Mielniczuk, J. (2008). Recomendação de adubação potássica para trigo, milho e soja sob sistema plantio direto no Paraguai. Revista Brasileira de Ciência do Solo, 32, 1929-1939.

Werle, R., Garcia, R. A., \& Rosolem, C. A. (2008). Lixiviação de potássio em função da textura e da disponibilidade do nutriente no solo. Revista Brasileira de Ciência do Solo, 32, 2297-2305. 